\title{
СРЕДНЕВЕКОВЫЕ АРХЕТИПЫ И БАЛКАНСКИЕ НАЦИОНАЛИЗМЫ ВОИН 1912-1913 г.
}

\author{
Румяна Комсалова
}

\begin{abstract}
Rumiana Komsalova, Средневековые архетипы и балканские наиионализмы воин 1912-1913 г. (Medieval archetypes and Balcan nationalisms in the wars in 1912-1913).

Balcanica Posnaniensia. Acta et studia, XIX, Poznań 2012, Wydawnictwo Instytutu Historii UAM, pp. 111-119, ISBN 978-83-63-047-17-7, ISSN 0239-4278. Russian text with a summary in English.

Rumiana Komsalova, Пловдивский университет «Паисия Хилендарского» - Болгария.
\end{abstract}

Берлинский договор создал новые государственно-территориальные статускво Балкан, но не сумел, а и не ставил целью, решить национальную проблему на полуострове. ${ }^{1}$ Под властью Османской империи остались обширные территории, населенные болгарами, сербами, греками и албанцами, а Австро-Венгрия к своим балканским владениям, населенным сербами, хорватами, словенцами и румынами, добавила еще Боснию и Герцеговину. Вот почему и в следующие десятилетия приоритетом в политике балканских государств (Румынии, Сербии, Греции, Черногории и Болгарии) остается стремление к освобождению территорий, населенных их соотечественниками, и к присоединению к матери-родине. Одинаковые цели и стремления балканских стран подразумевают их единые действия. Но это оказалось трудно осуществимо, так как отдельные балканские государства, используя различные аргументы, очень часто претендуют на одни и те же территории. Обстановка осложнялась и политикой „разделяй и владей” Великих сил, которые, по существу разжигают соперничество между балканскими народами и противопоставляют их друг другу.

Национальные противоречия Балкан в рассматриваемом периоде, во-первых, между балканскими государствами с одной стороны и Османской и АвстроВенгерской империями с другой, и, во-вторых, между самими балканскими государствами. Первой спорной территорией является Македония, на которую пре-

\footnotetext{
${ }^{1}$ Международни актове и договори 1648 - 1918 г., С., 1958, 155-168.
} 
тендуют Болгария, Греция, Сербия и даже Румыния; второй - Фракия, о которой спорят Болгария и Греция; третьей - Албания, Косово и Новопазарский санджак, где сталкиваются интересы албанского национально-освободительного движения и Греции, Сербии и Черногории. Кроме того, Берлинским договором Румынии предоставлена Северная Добруджа, а Сербии - Нишский санджак, что сформировало еще две конфликтных зоны между Болгарией и ее двумя соседками. ${ }^{2}$

Каждое из Балканских государств формирует свою концепцию разрешения своих национальных проблем, причем различия в основном связаны с методами и средствами ее реализации.

Основной проблемой Греции является вопрос о положении греков под османской властью и эвентуальном освобождении и присоединении Тесалии, Эпира, о. Крит и пр. Но вместе с тем на основании так называемой „Мегали Идеа" предъявляются претензии к Македонии, в которой преобладают болгары, и к территориям, населенным албанцами. ${ }^{3}$

Румыния чувствует себя ущербной Берлинским договором, поскольку у нее отнимается Южная Бессарабия, а данная ей в качестве компенсации Северная Добруджа принимается без восторга всей румынской общественностью. При этом учитывается и факт, что там нет румынского населения. Что касается так называемых „куцовласов” в Македонии, то через них аргументируются ее территориальные претензии к Болгарии, обоснованные в качестве компенсации болгарского расширения там. ${ }^{4}$

Сербия конструирует свою национальную концепцию на основе „Начертания” Илии Гарашанина. ${ }^{5}$ Но очерчиваются определенные нюансы в ее реализации: во-первых, территориальное расширение на восток и юго-восток к Болгарии и Македонии с поддержкой Австро-Венгрии; во-вторых, противопоставление Австро-Венгрии присоединению Боснии и Герцеговины, и в третьих, параллельное осуществление обеих целей. Имеются различия в методах их осуществления. Так, например, радикалы Н. Пашича и либералы Й. Ристича указывают на необходимость в союзе балканских народов и „братское сотрудничество с Болгарией и Черногорией” против Османской империи. ${ }^{6}$ Но в 90 -ые

\footnotetext{
2 Манчев, К. История на националния въпрос на Балканите. С., 2008, 91-96; Грънчаров, Ст. Балканският свят. Идеи за държавност, национализми и развития от началото на XIX век до края на Пьрвата световна война. С., 2001.

3 Данова, Н. Към въпроса за българо-гръцките отношения през последното десетилетие на XIX век. - B: Националноосвободителни движения на Балканите в края на XIX век. Studia balcanica, 12, C., 1976; Поплазаров, Р. Грчката политика спрема Македонија во втората половина на XIX и почетокот на XX век. Скопије, 1973.

${ }^{4}$ Арабов, В. Размяната на Добруджа с Бесарабия. Отказът на румъните от Добруджа. Участието на Румъния в Руско-Турската война 1877-1878 г. С., 1939;

${ }^{5}$ Манчев, К. Проблеми на сръбската външна политика в края на XIX век (1889 - 1892). В: Националноосвободителни движения на Балканите..., 65-95.

${ }^{6}$ Божилова, Р. Сърбия и българското националноосвободително движение в Македония в края на XIX в. (1894 - 1896). - Известия на института за история, 25, 1981.
} 
года XIX в. комментируется „болгарская опасность” и идет поиск союзников для проникновения сербов в Македонию в лице Греции, России и Цареградской патриархии. Проводником этой политики является общество Св. Савы, а общество „Великой Сербии” настроено против австро-венгерского господства в Боснии и Герцеговине. Если на востоке великая сербская концепция в конфронтации с Болгарией, то на западе она вступает в противоречие с хорватской национальной концепцией о „Великой Хорватии”. Альтернатива этой конфронтации на западе - югославизм, согласно которому сербы, хорваты и словенцы являются одним народом с тремя названиями. У югославизма также есть определенные нюансы - хорватский вариант предусматривает объединение южных славян (сербов, хорватов и словенцев) в отдельную единицу федерации в рамках Австро-Венгерской империи, в то время как сербский вариант - их объединение с Сербией и Черногорией в отдельное южнославянское государство. Эта идея постепенно внедряется в сербскую политическую жизнь с 1903 г., а ее пропагандистом является созданное в Белграде общество „Словенский юг”. Оно защищает тезис о единстве четырех южнославянских народов - сербов, хорватов, словенцев и болгар, и выдвигает лозунг: “Южные славяне, объединяйтесь!”.

Таким образом, очерчиваются различные концепции решения национальных проблем на Балканах, причем одни из них основываются на великодержавии, а другие берут за основу федерализм. Великодержавные концепции взаимно исключают друг друга, в то время как идея о федерации является основой для общих действий балканских народов против господства двух империй на Балканах. Эта идея формируется еще в период Балканского возрождения и становится одной из ведущих в программах и взглядах деятелей возрождения, особенно в XIX веке, под сильным влиянием Европейского просвещения. Параллельно с этим ее корни можно найти в прошлом, включая и Средневековье, когда на Балканах доминировала политическая доктрина византийского ойкуменизма, тесно переплетающаяся с православным христианством.

Основные концепции византийской ойкуменистической доктрины формируются в период VII-X веков, но консервированная в традициях религиознополитической жизни, она воздействует с неослабевающей силой и в период позднего Средневековья, когда сама империя находится в упадке. Определенный вклад в ее формирование имеет христианская церковь, тесно переплетенная в своих интересах с имперской властью. На протяжении нескольких веков уважаемые богословы и канонисты моделируют идейно-теоретический византийский ойкументизм. ${ }^{8}$ Он был подчинен христианскому провиденциализму о месте, роли и значении Византии, „второго Рима” в „целостной христианской империи”. Эта „целостная христианская империя”, хоть и управлялась вне границ Византии независимыми владетелями, имела один центр

\footnotetext{
7 Манчев, К. История на балканските народи (1878-1918). II, С., 2006, 100-105.

8 Караянопулос, Й.Е. Политическата теория на византийците. С., 1992.
} 
- Константинополь, и одного императора-отца, высочайшего повелителя всех христианских владетелей. ${ }^{9}$

После большой схизмы в 1054 г., глобально-политические стремления Византии ограничились измерениями восточно-православного мира. В восточно-ортодоксальном ареале, она возвысилась как центр и хранитель православия. Даже такие самостоятельные государства, как Болгария и Сербия настойчиво стремились к византийскому признанию политического суверенитета и церковной автокефалии. В Константинополе осознавали, что прима василевса и патриарха имели идейное, символическое значение, но при всем этом ревниво отстаивали его.

С конца XI века начала прокладывать себе путь идея об этнокультурной целостности греков, которая постепенно начала приобретать политический оттенок. Под номинацией “ромей” уже понимался грек. Интересно отметить, что после X века на престоле нет ни одного императора не греческого происхождения. Сознание ортодоксального исповедания сочетается с этническим самосознанием, что заставило космополитических в прошлом ромеев почувствовать себя эллинами (греками). ${ }^{10}$

C XIII века Церковь в византийском обществе взяла на себя функции консолидирующего фактора, который содействует греческому национальному самосознанию. В обстановке религиозной ревности и антилатинских настроений, православие становится знаком „национальной принадлежности”. Простолюдины из чувства самосохранения ориентируется на православие, а интеллектуальная элита - на идеи эллинизма. В этой обстановке рождается последняя византийская идея - „великая идея” из которой берет свое начало новогреческий патриотизм. ${ }^{11}$

В Средние века в сформировавшейся таким образом восточно-православной общности доминирует ойкуменическая идея Византии, что все земли подвластны византийскому василевсу. Но балканские владетели предпринимают попытки изъять эту идею и трансформировать ее в славяно-византийский православный вариант. Первая попытка была сделана болгарским владетелем Симеоном (893-927), который попытался "обновить" Восточную империю, наложив болгарскую доминацию. Его целью было через овладение византийского императорского института стать признанным „василевсом ромеев”. ${ }^{22}$ В XIII в., в результате возникших для Византии последствий IV крестоносного похода и униатского курса Палеолога Византия в 70-ые годы века среди болгарской политической элиты зарождается идея „Тырново как Третий Рим”, т.е. предпринимается свое-

9 Бакалов, Г. Ролята на византийската ойкуменическа доктрина в политическия живот на Московска Русия. - Ипр., 1980, № 5, 83.

10 Бакалов, Г. Византия.Културно-политически очерци. С., 1999, 308.

${ }^{11}$ Хунгер,Х. Империя на ново средище. С., 2000, 80.

12 Божилов, И. Цар Симеон Велики. С., 1983. 
образная попытка изъять функции „Второго Рима” - Константинополя, как символ истинного православия. ${ }^{13}$

A в XIV в. сербский владетель Стефан Душан (1331-1355) также предпринимает попытку создать южнославянскую византийскую православную империю. Объявив себя “царем сербов и ромеев” и он, подобно Болгарии, “обсербил” византийскую ойкуменическую идею. ${ }^{14}$

Завоевание византийской столицы Константинополя османскими турками в 1453 г. - это событие, имеющее непосредственное отношение к судьбе балканских народов. ${ }^{15} \mathrm{C}$ уничтожением Византии как политической силы на Балканах, Константинопольская патриархия лишилась государственного покровительства со стороны православного владетеля. Но через систему „Рум милета”, созданную османским султаном Мехмедом II, Патриархия смогла объединить всех православных христиан на Балканах и представлять их по всем вопросом перед османским владетелем. ${ }^{16}$ Так они объединились в общее государство, которое чуждо сформировавшейся славяно-византийской православной модели. Это стало предпосылкой для формирования чувства принадлежности к одной и той же общности, целью которой является отвержение чужой политической власти. Но параллельно с этим начался и процесс формирования национальных идеологий и стремление к национальной идентичности отдельных православных балканских народов, который отражает основную сущность Балканского возрождения. Появляются книжные произведения, в которых взгляд обращается к средневековому прошлому, к тому, что связывает балканские православные народы. Такого характера и „Стематография” Христофора Жефаровича, напечатанная в 1741 г. в Вене, в которой присутствовали гербы всех славянских народов, лики болгарских и сербских владетелей и святых. Позднее, Паисий написал свою „Историю славяно-болгарскую” (1762 г.), а немногим позже после этого появилась "История разных словенских народов и най-паче Болгар, Хорватов и Сербов” (1794-1795г.) Йована Раича. Постепенно прокладывает себе путь идея о общебалканском единодействии в борьбе против чужой политической власти османских турков и создании балканской федерации. Первым выразил эту идею Ригас Велестинлис (1757-1798г.). Под влиянием идей Великой французской революции он стал убежденным республиканцем. В нескольких доку-

13 Бакалов, Г. Универсалистки аспекти в идеята за “третия Рим”-Духовна култура, 1992,.4, с.23; Тъпкова-Заимова, В. Българо-византийските отношения и концепциите за “втория” и “третия” Рим - сб. Изследвания в чест на акад. Н.Тодоров, С.1983, с.35-36.; Тъпкова-Заимова,В. Търново между Ерусалим, Рим и Цариград. - Сб.Търновска книжовна школа, т.IV,C.1985, с.251-252.; Андреев, Й. Идеята за Третия Рим: Търновската книжовна школа и Григорий Цамблак. - Трети международен симпозиум “Търновска книжовна школа”. В.Търново, 1980.

14 Оболенски, Д. Византийската общност. С., 2001; Матанов, Хр. Средновековните Балкани. C., 2002.

15 Новичев, А. История Турции. Т. І. Ленинград, 1963, 76; Османская империя и страны Центральной и Юго-восточной Европы в XV-XVI вв. Москма, 1984, 33-34;

16 История на Османската империя. С., 1999, 415-417. 
ментах программы - “Декларация”, “Конституция” и “Карта Греции”, Ригас Велестинлис защищал идею общебалканской революции при поддержке революционной Франции. ${ }^{17}$ На руинах Османской империи предусматривалось создание одной большой республики, в которой все народы будут жить при полном равенстве. Она должна была называться "Греческая республика, в которую входят греки, болгары, албанцы, власы, армяне, турки и любой другой род, без различий в религии и языке”. Доминация греческой нации засвидетельствована в обязательном греческом языке для всех школ. ${ }^{18}$ В 1797 г. Ригас издал свою книгу “Странствования молодого Анахарсиса”, вместе с картой территорий, которые будут входить в “греческую республику"19, а это земли, населенные православными христианами, объединенными в Средние века в византийское ойкумене. Влияние византийской политической доктрины в данном случае скорее географическо-культурное, чем политическое, поскольку Ригас Велестинлис исключает “богоизбранность” определенного народа, ярко выраженную в византийском ойкуменизме через идею о династии владетелей.

В противовес его демократическим республиканским идеям, среди “фанариотов" и формирующейся греческой буржуазии, возникла так называемая “Великая идея” (Мегали Идеа). Она в определенной степени возрождает византийский ойкуменизм, так как ее целью является восстановление “Византии”, как греческого государства, включающего всех православных христиан на Балканах. Подобный проект был создан и княжеством Сербии. Под влиянием крыла польской эмиграции, возглавляемого Адамом Чарторийским, премьер-министр Сербии Илия Гарашанин в 1844 г. составил так называемое “Начертание”, в основе которого лежит дух Стефан-душановской империи XIV в. В этом документе предусматривалась ликвидация османской власти на Балканах и создание мощного южнославянского государства, под управлением сербской династии. Цель: объединение всех южных славян, при этом Сербия будет играть руководящую роль. Но так как в этом проекте на передний план выведена общность южного славянства и православия, к ней приобщаются и некоторые деятели и организации болгарского освободительного движения. В их числе Георги Раковски, Любен Каравелов, Добродетельная дружина и Одесское болгарское настоятельство. Для Любена Каравелова основной характеристикой будущей Балканской или Дунайской федерации была “свобода народная, свобода личная и свобода религиозная”. Василу Левскому представлялась Балканская демократическая республика в еще более демократическом варианте: основанная на равном положении входящих в нее народов.

При анализе византийской политической доктрины ойкуменизма становится ясно, что как бы ни была далека эта идея от современного понимания федерации, все-таки она создала чувство единства, идентичности и близости балкан-

17 Велестинлис, Р. Революционно. С., 1998, 13-17.

18 Там же, 46.

19 Димитров, Стр., К. Манчев. История на Балканските народи. XV-XIX век. С., 1971, 177-178. 
ских народов, т.е. их принадлежности к одному и тому же кругу цивилизации, основанному на православии. Позднее, в условиях османского господства и появления национально-освободительных движений, ойкуменизм оказывает свое влияние как при формировании мегаломанских идей балканской буржуазии, так и при формировании политических доктрин революционно-демократических течений. В первом случае воспринимается конструкция субординации ойкуменизма, причем верховная власть византийского императора заменяется верховной властью отдельной нации, национального государства или династии. Во втором случае балканские демократические течения восприняли не эту конструкцию, а созданное еще в Средневековье чувство принадлежности к одной и той же цивилизацонной модели - православной славяно-византийской общности.

Идея о федерации балканских народов в том или ином варианте присутствует в политических программах балканских государств. Но каждый вкладывает различные нюансы, где более демократичные, где с большим или меньшим националистическим-шовинистическим аспектом.

Точка зрения Греции на федерацию на Балканах отражена в созданной в 1883 г. так называемой Восточной федерации, во главе с Леонидасом Вулгарисом. В своем письме Захарию Стоянову от 1888 г. он пишет, что „Восточная федерация объединит в себе Румынию, Сербию, Черногорию, Албанию-Македонию, Грецию и Болгарию и, если возможно, Турцию, став, таким образом, столбом безопасности в Европе". ${ }^{20}$

Федерализму уделено место и в программе сербской Радикальной партии Николы Пашича, провозгласившей себя “союзом балканских народов”, т.е. Балканской конфедерацией, на основе национального, религиозного и политического равноправия, „причем каждый жертвует чем-то из своих стремлений”. ${ }^{21}$

Балканские социал-демократические партии в свою очередь на конференции, состоявшейся в 1909 г. в Белграде, приняли концепцию Балканской федеративной республики, которая выдвигается руководителями болгарской и сербской социал-демократии Д. Благоевым ${ }^{22}$ и Д. Туровичем. Федерализм воспринимается и деятелями болгарского национально-освободительного движения Македонии и Фракии, и особенно левых сил во главе с Яне Санданским. ${ }^{23}$

Одна из основных проблем Балкан - болгарская национальная проблема, вызванная решениями Берлинского договора. Ее решение подразумевает освобождение болгарских этнических территорий от чужой власти и их объединение в общее государство. В основе болгарской национальной доктрины заложены несколько основных документов, санкционированных Османской властью и Великими силами, а именно: Ферман от 28.02.1870 г. об учреждении Болгарской экзархии, проект

\footnotetext{
${ }^{20}$ Манчев, К. История на балканските народи..., 245-246.

21 Там же, 246.

22 Благоев, Д. Балканска федерация. -В: Благоев, Д. Съчинения, І, С., 1957.

23 Пандев, К. Националноосвободителното движение в Македония и Одринско 1878 - 19-3. C., 1979.
} 
Цареградской конференции послов от XII 1876 г., и Сан-Стефанский договор, подписанный между Россией и ее союзниками с Османской империей. Этот договор сравнительно справедливо решает как болгарскую, так и общебалканскую национальную проблему. Именно эти три документа, и в особенности Сан-Стефанская Болгария, лежат в основе концепций болгарских политических партий. Различия сводятся в основном к методам и средствам осуществления болгарского национального идеала. Основной противник - Османская власть в Македонии и Фракии, но параллельно с этим усиливаются стремления Греции и Сербии, а также активизируется вооруженное албанское вмешательство в поддержку османской власти. В этой ситуации болгарская политика направлена в первую очередь на отстаивание и сохранение болгарского этнического самосознания в этих областях, рассчитывая для достижения цели более всего на Болгарскую экзархию. В этом отношении первоначально болгарское правительство имеет поддержку России, а с конца 80-ых годов XIX в., когда Россия начинает поддерживать стремления Сербии к Македонии, рассчитывается в основном на Османскую управляющую среду, как ни парадоксально это звучит. Вторая основная цель - проведение реформ, предусмотренных в статье 23 Берлинского договора, которые приведут к действительной автономии христианского населения в европейских вилайетах Империи. Эта цель залегла и в программу созданной в 1893 г. $\mathrm{BMOPO}^{24}$, но всем заинтересованным было ясно, что истинной целью является автономия как этап объединения с Болгарией. Пиком в национальной борьбе болгар в Македонии и Одринском районе против османской власти стало Илинденско-Преображенское восстание 1903 г. $^{25}$, но его погашение и невозможность Болгарского государства вмешаться, постепенно навязывают в качестве единственной альтернативы войну с Турцией.

Для объединения балканских государств в общий союз против османской империи необходимо искать путь разумного компромисса и в первую очередь по вопросу с Македонией. Болгария постепенно отходит от своей жесткой политики о неделимости этой области и принимает сербский и греческий тезис о ее разделе. Только этой ценой заключается Сербско-Болгарский договор от 29.02.1912 г., который становится своего рода позвоночником Балканского союза против Османской империи. ${ }^{26}$

Чтобы навязать путь к войне и объединение Балканских христианских государств в военный союз имело значение, и монархический фактор, и особенно политика царя Фердинанда, который сумел ловко манипулировать как политическими силами, так и общественным мнением.

В заключение можно сделать вывод, что средневековая балканская реальность оказала свое серьезное влияние на балканские государства при их попытках решить свои национальные проблемы путем войны. Таким образом, ви-

${ }^{24}$ Гоцев, Д. Идеята за автономия като тактика в програмите на националноосвободителното движение в Македония и Одринско, 1893 - 1941. С., 1983.

25 Панайотов, Л. Илинденско-Преображенското въстание 1903. С., 1984.

${ }^{26}$ Международни актове и договори 1648 - 1918 г. С., 1958, 317-320. 
зантийская политическая доктрина, основанная на идее, что империя призвана навязать варварскому миру христианскую религию, трансформируется в период Балканского возрождения в так называемую «Мегали Идеа» и находит свое отражение в политических целях Греческого королевства во времена Балканских воин.

Болгарский средневековый архетип, выраженный в идее Симеона о болгаровизантийской империи со столицей Константинополь и в сформировавшейся в XIII веке концепции «Тырново - Третий Рим» дала основание Паисию Хилендарскому провоцировать национальное самосознание. Апогей вожделений возрождения - Сан-Стефанская Болгария не был реализован, но породил миф «Болгария на трех морях», который толкал государство к войне как к пути национального объединения.

Третий «игрок» на балканской сцене - Королевство Сербия, в свою очередь ищет основания в империи Стефана Душана и ее варианте в эпоху возрождения - «Начертания» Илии Гарашанина.

Поэтому Балканский союз, созданный во имя благородной и справедливой цели - освободить своих «собратьев» христиан от гнета Османской исламской империи, оказался заминированным еще в зародыше этими по существу имперскими проектами.

\title{
MEDIEVAL ARCHETYPES AND BALKAN NATIONALISMS IN THE WARS IN 1912-1913
}

\author{
Summary
}

The Medieval Balkans are characterized by three basic imperial archetypes - Byzantine ecumenism and the imperial ideas of Bulgarians and Serbians.

The Byzantine political doctrine based upon the idea that the empire is called upon to impose the Christian religion over the barbarian worlds was transformed throughout the period of the Balkan Revival into the so-called „Megali idea” and found its reflection in the political goals of the Greek Kingdom during the Balkan Wars.

The Bulgarian Medieval archetype, expressed in Simeon's idea of a Bulgarian-Byzantine empire with Constantinople as its capital and in the concept that took shape in the XIII-th century of „Tarnovo the Third Rome", gave Paisii Hilendarski grounds to provoke the national self-conscience. The apogee of Renaissance aspirations, San Stefano Bulgaria, was not realized but it gave birth to the myth of „Bulgaria bordering three seas", which pushed Bulgaria into the wars as a road to national union.

The third ,player" on the Balkan scene - the Kingdom of Serbia in its turn sought its grounds in Stefan Dushan's empire and its Renaissance version - the „, Načertanije” of Ilija Garašanin.

Thus, the Balkan union, created in the name of a noble and just cause - to liberate their Christian „brothers" from the oppression of the Ottoman Islamic Empire, turned out in its very bud to be on mined land by these projects imperial in their nature. 
